\title{
Second European Congress of Allergology
}

The Second European Congress of Allergology was held in Copenhagen, May 21, through May 23, 1953, inclusive, at the University of Copenhagen. The Northern Society for Allergological Research had charge of the arrangements for this Congress and this society in turn entrusted the arrangements of the Second European Congress to the Danish Society for Allergological Research. The Danish Society announced that the Second European Congress of Allergology was held under the auspices of the International Association of Allergology. Dr. Fred. W. Wittich, President of the I.A.A., participated in the Congress as a guest of honour.

Dr. Thorvald Madsen of Copenhagen and Professor Pasteur Vallery-Radot of Paris assumed the posts of Honorary Presidents of the Congress. The officers who were present were: Professor Poul Bonnevie, M.D., Vice-President; Egon Bruun, M.D., Secretary-General; and Secretaries Erik Andersson, M.D., P. J. Dragsted, M.D., and Michael Schwartz, M.D. President Ernst B. Salen was unable to attend because of illness, therefore, First Vice-President, Professor Dr. Poul Bonnevie acted as Chairman of the meeting.

The mornings of May 21 to 23, were reserved for plenary meetings. The meetings on the afternoons of May 21 and 22, were reserved for meetings of individual sections.

372 Proceedings - Sociétés - Gesellschaftsberichte

The scientific Program was held at the Medico-Anatomical Institute. All reports were delivered in English, French, or German at the officers choice. Approximately three hundred were registered for the Congress.

The Scientific Program commencing Thursday morning May 21, and ending Saturday May 23, was as follows:

1. Principal Subject: Allergy and Adrenal Hormones. R. J. S. McDowall, London: Physiological Activity of the Adrenal Hormones. P. Vallery-Radot, P. Milliez and C. Laroche, Paris: Les hormones cortico-surrénales dans le traitement des maladies allergiques respiratoires. Åke Nilzén, Stockholm: Adrenal Hormones and Derma-tologic Allergy. J. Groen, Amsterdam: Treatment of Bronchial Asthma with Combination of ACTH and Psycho-Therapy.

Discussion announced in advance Z. Eriksson-Lihr, Helsingfors: The Correlation between Adrenal and other Hormones in Allergy. - L. Businco, Rome: L'action de la cortisone sur les divers organes (etude histologique). - M. Damas Mora, Lisboa: Valeur de ГACTH dans le traitement de quelques maladies allergiques. - W. J. Quarles van Ufford, Utrecht: Adrenal Function Tests and Allergic Diseases.

Free Subjects Section A A. A. Israels and Dingemanse, Groningen: The Excretion of Neutral 17Ketosteroids of Adrenal and Gonadal Origin in Bronchial Asthma with and without a Bacterial Bronchitis. - P. Sangiorgi, Milano: Results of Application of ACTH in Retard Vehicle (Corticotropin Retard Roskilde) given intracutaneously in Cutaneous and Respiratory Allergy.Z. Eriksson-Lihr, Helsingfors: Studies on the Carbohydrate Metabolism in Allergic Diseases. G. Capuani, E. Clerici and L. Teseo, Milano: La réponse cortico-surrénale à Гinjection endoveineuse de ACTH dans les malades de rhinite allergique au dehors et à la suite de la crise. H. van Canwenberge and J. Lecomte, Liège: Hormones Cortico-surrénaliennes et accroissement 
de perméabilíté vasculaire par Thistamine chez le rat. - R. Masturzo, Napoli: L'ACTH en quelques dermatoses allergiques. - H. Colldahl, Lund: The Pulmonary Acetylene Elimination Capacity (P.A.E.C.) of Intravenously Administered Acetylene. A New Test of Pulmonary and Cardiovascular Function. - G. Capuani, Novara: Traitement de Гasthme bronchique grave par une méthode de neurolyse alcoolique.

Section B

G. Filipp, Debrecen: Allergie und Zentralnervensystem I. - A. Szentivanyi, Debrecen: Allergie und Zentralnervensystem II. - Vera Walker, Oxford: Manifestations of Allergy in the Central Nervous System. - Walter Roloff, Leipzig: Die Korrelation der Atmung und der vegetativhormonalen Regulation - die Atmung als Grundlage allergischer Disposition. - Udo Pipkorn, Göteborg: Er-fahrungen mit Hornhauttestungen bei verschiedenen allergischen Erkrankungen. H. Arnoldsson and Udo Pipkorn, Göteborg: Elektrophoretische Studien unter Androgentherapie bei Asthma bronchiale. - F. J. Farrerons \& Co., J. M. Samso Dies, J. Vila Badó and L. Pau-Roca: Electroencephalography in Asthmatic Children. - A. A. Israels and N. G. M. Orie, Groningen: Some Endocrine Observations in Infected and Non-Infected Asthma. - J. Tabart, Paris: Allergie endocrinienne. -A. Mugler, Strasbourg: L'Action Anti-allergique des derives du Colchique (Colchicine, Colchicoside).

Friday, May 22

2. Principal Subject: Allergy and Infection. - E. Letterer, Tubingen: Allergie und Infektion, vom pathologisch-anatomischen Gesichtspunkt gesehen. -

Proceedings - Sociétés - Gesellschaftsberichte $\quad 373$

P. Bordet, Bruxelles: Données immunologiques concernant $\Gamma$ allergie au cours des infections. C. Jimenez-Diaz and E. Arjona, Madrid: Le role des infections dans Tétiologie des maladies allergiques.

Discussion announced in advance V. Danilovic and V. Spoujitch, Beograd: L'asthme et infection. - H. van Marken Lichtenbelt, Zeisten, and W. J. Quarles van Ufford, Utrecht: Some Observations during Anti-infection Therapy of Allergic Diseases. - J. Duchaine, Bruxelles: Allergy and Infection. - Felix O. Höring, Worms: Hyperergie bei zykli-schen Infektionskrankheiten und ihre Therapie mit spezifischen und unspezifischen (Pyrifer, Cortisone) Maßnahmen. - N. G. M. Orie, Groningen. - R. Frouchtman, Barcelona: L'inflammation bronchique dans Гasthme ínfectueux.

Free Subjects Section A George L. Waldbott, Detroit: The Mechanism of Allergic NonInfectious Pneumonitis. - Diether G. R. Findeisen, Dresden: Erfahrungen mit der Aerosolinhalationsbehandlung des infektionsallergischen Asthmas. - S. Bergman and H. Colldahl, Lund: A comparison between the Bacterial Flora in Sputum and in Bronchial Secretions in Patients with Bronchial Asthma. - H. Schmidt, Marburg: Die Rolle der Autoantikörper für das allergische Geschehen. - K. Hansen, Lübeck: Über den Prausnitz-Küstnerschen Versuch. - R. Schleinzer, Lübeck: Über den Prausnitz-Küstnerschen Versuch. Ergebnisse bestimmter Varianten seiner Aus-lösung. - O. Midttun, Sunndalsera, Norway: Anaphylactic Death Following Injection of Allergentract by Sensibilisation. - J. Hugues and J. Lecomte, Liège: Etude microcinématographique des reactions allergiques locales (film).

Section B B. N. Halpern and Mile M. Briot, Paris: Etude des polymères comme substances histaminolibératrices. - Z. Ovary, Rome: A New Method of Differentiation of Heterophyle and Isophyle Antibodies in Rabbit Antisheepsera. - L. Businco, Rome: L'action antianaphylactique de la moutarde azotée. - Fr. Kogoj, Zagreb: Superponierte Tuberkulin und 
Trichophytinreaktionen. - J. Alberty, Göttingen: Experimentelle Untersuchungen über den Mechanismus der anaphylaktischen Reaktion und die anaphylaktische Wirkung von Atropin und Tripelendiamin. -C. Cavallero, Milano: Plasma Cells and Somatotrophic Hormone. - R. Masturzo, Napoli: La Vitamine B12 synthétique en quelques dermatoses. - C. Jimenez-Diaz, J. Segovie and E. Arjona, Madrid: Nouvelle technique de la microprécipitine reaction. - G. Biozzi, N. N. Halpern and B. Benacerraf: Conditions Influencing the Local Fixation of Antibodies in Passive Cutaneous Anaphylaxis of the Guinea Pig.

Saturday, May 23 Open discussion Rosa Augustin, London: Isolation and Characterisation of the Active Components of Grass Pollen Extracts. - Z. Ovary and F. d'Ermo, Rome. - Fred. W.

Wittich: The Present Status of Drug Therapy in the Treatment of Allergic States. Round Table Conference: The Problem of Specificity.

A. Tzanck, Paris, B. N. Halpern, Paris, A. Fagraeus, Stockholm, Ouchter-lony, Gothenburg, E. Bruun, Copenhagen.

Presidential Address

End of the Congress

Limited space will not permit the reporting of the abstracts of the various

topics and discussions presented. Proceedings will be published either in extenso in the proceedings of the Acta Allergologica commencing with Vol. VI supplementum III or subsequently in one of the ordinary fascicles of the Acta. 